\title{
Pelatihan Pemantapan Penguasaan Bahan Ajar IPA Terintegrasi Nilai-Nilai Al-Qur'an Pada Guru-Guru SD Kab. Indragiri Hulu
}

Siti Robiah ${ }^{1}$, Suryanti ${ }^{1}$, Sepita Ferazona ${ }^{1}$

${ }^{1}$ Program Studi Pendidikan Biologi, Fakultas Keguruan dan Ilmu Pendidikan, Universitas Islam Riau, Jalan.KH.Nasution No 113 Marpoyan, Kota Pekanbaru, Propinsi Riau, Indonesia - 28284

*Penulis koresponden: sitirobiah@edu.uir.ac.id

Info Artikel

\section{Riwayat :}

Dikirim 20 Desember 2021

Direvisi 10 Januari 2022

Diterima 11 Januari 2022

\section{Kata Kunci :}

Pelatihan

Bahan Ajar IPA

Alqur'an

Guru-Guru SD

\begin{abstract}
Abstrak
Ilmu Pengetahuan Alam merupakan ilmu yang memiliki karakteristik berbeda dengan ilmu yang lain yakni mengandung ayat-ayat Qauniah dan ayat-ayat Qauliyah sehingga butuh skill dan bahan ajar tersendiri dalam mentransfer ilmunya. Namun demikian pelaksanaan proses pembelajaran yang dilakukan guru-guru SD IPA masih bersifat parsial dengan hanya mengutamakan target capaian ayat-ayat Qauniah semata (aspek kogitif IPA) sehingga aspek qauliyah terutama sikap islami terabaikan, disamping itu memang masih kurangnya bahan ajar IPA yang terintegrasi nilai-nilai Alqur'an yang bisa dijadikan i acuan bagi guru-guru SD. Sebagai solusi terhadap permasalahan tersebut maka guru-guru SD perlu dibekali melalui suatu pelatihan pemantapan penguasaan bahan ajar IPA terintegrasi nilai-nilai alqur'an agar dapat diaplikasikan kepada peserta didik.
\end{abstract}

\section{PENDAHULUAN}

Tujuan Pendidikan Islam tidak terlepas dari tujuan hidup manusia dalam Islam, yaitu menciptakan pribadi hamba Allah yang selalu bertaqwa kepada-Nya dan berakhlak mulia, rahmatan li al-alamin, serta bahagia dunia dan di akhirat. Pendidikan bertujuan membentuk insan al-kamil (manusia paripurna) yang memiliki akhlak qurani atau manusia yang beriman dan bertakwa serta memiliki berbagai kemampuan yang teraktualisasi dalam hubungannya dengan Tuhan, dengan sesama manusia, dan dengan alam sekitarnya secara baik, positif, dan konstruktif, terciptanya insan yang kaffah dalam dimensi agama, budaya dan ilmu. selanjutnya penyadaran fungsi manusia sebagai hamba Allah ('abdillah) dan wakil Tuhan di muka bumi (khalifah fil ardh). Adapun manusia ditinjau dari segi fungsinya sebagai khalifah, maka aspek yang perlu dikembangkan yaitu aspek pemahaman, penguasaan, dan tanggung jawab terhadap kelestarian alam raya. Berkenaan dengan itu, maka perlu dikembangkan aspek pendidikan ilmu pengetahuan dan aspek pendidikan moral serta aspek keterampilan pengelolaan alam raya. (Jayadi, I: 2018; Nasution, AS, Lubis, SA, dan Mukti, A, 2019; Siregar, B, Zein A dan Zulheddi, 2019; Azra ,2012; Gunawan, 2014)

Relevans dengan hal tersebut, Undang Undang Dasar Negara Republik Indonesia Tahun 1945 mengamanatkan pemerintah mengusahakan dan menyelenggarakan satu sistem pendidikan nasional yang meningkatkan keimanan dan ketakwaan kepada Tuhan Yang Maha Esa serta akhlak mulia dalam rangka mencerdaskan kehidupan bangsa yang diatur dengan undang-undang. Implikasi dari hal tersebut dalam Undang-Undang SISDIKNAS No. 20 Tahun 2003 Pasal 3, Pendidikan Nasional bertujuan untuk berkembangnya potensi peserta didik agar menjadi manusia yang beriman dan bertaqwa kepada Tuhan Yang Maha Esa, berakhlak mulia, sehat, berilmu, cakap, kreatif, mandiri, dan menjadi warga negara yang demokratis serta bertanggung jawab.

Berdasarkan uraian diatas dapat disimpulkan bahwa melalui pendidikan diharapkan manusia mampu mengembangkan seluruh potensi yang dimilikinya sehingga berfungsi maksimal sesuai dengan aturan-aturan yang digariskan oleh Allah SWT dan Rasulullah SAW yang akhirnya terwujud manusia yang paripurna (Insan-kamil). Dengan demikian, lulusan yang bermutu tinggi adalah seorang mukmin yang memiliki ilmu (kognitif/knowledge), dan mampu memanfaatkan ilmunya dalam kehidupan, 
sebagai amalnya (motorik/skill) denga akhlak mulia (nilai dan sikap/attitude), sehingga berdampak rahmatan lil alamin. Lulusan yang bermutu, memiliki pribadi yang integral, yaitu integrasi antara iman, ilmu, dan amal.

Namun demikian berdasarkan fenomena dan fakta dilapangan serta data yang ada menunjukan adanya kegagalan dalam pencapaian tujuan pendidikan di Indonesia. Mutu pendidikan di Indonesia masih sangat rendah. Hal ini ditunjukan oleh berbagai indicator diantaranya , berdasarkan Human Development Indeks tahun 2012 Indonesia peringkat ke 125 diantara 180 Negara, Tahun 2013 peringkat ke 121 diantara 185 Negara (UNDP), kemudian berdasarkan. PISA (Program for International Student Assesment) 2006 yang berfokus pada literasi IPA mengukuhkan peserta didik di Indonesia menempati posisi ke-50 dari 57 negara peserta dengan skor rata-rata 393). Demikian pula hasil analisis PISA (Program for International Student Assessment) 2009, ditemukan bahwa dari 6 level kemampuan yang dirumuskan di dalam studi PISA, hampir semua siswa Indonesia hanya mampu menguasai pelajaran sampai level 3 saja, sementara negara lain yang terlibat di dalam studi ini banyak yang mencapai level 4, 5, dan 6. Dengan keyakinan bahwa semua manusia diciptakan sama, interpretasi yang dapat disimpulkan dari hasil studi ini, hanya satu, yaitu yang kita ajarkan berbeda dengan tuntutan zaman.

Disamping rendahnya prestasi akademik, juga kecendrungan terjadinya degradasi moral yang sangat memperihatinkan seperti tawuran pelajar antar sekolah, kecurangan ketika ujian, penyalahgunaan narkoba, pergaulan bebas dan sebagainya. Fenomena tersebut jelas telah mencoreng citra pelajar dan lembaga pendidikan, karena banyak orang berpandangan bahwa kondisi demikian berawal dari apa yang dihasilkan oleh dunia pendidikan dan dampak negatif dari kemajuan informasi teknologi di era digital, hal ini menunjukkan penyimpangan terhadap nilai yang terdapat dalam Alquran sendiri. (Nafila, NH, $d k k, 2016$; Darnanengsih, 2020; Marzuki,2015).

Berdasarkan hasil survey Komnas Perlindungan Anak bekerjasama dengan Lembaga Perlindungan Anak (LPA) (dalam Amri Syafri, U. 2014,2-3), di 12 provinsi pada 2007 diperoleh pengakuan remaja bahwa sebanyak 93,7\% anak SMP dan SMU pernah melakukan ciuman, petting, dan oral seks; sebanyak 62,7\% anak SMP mengaku sudah tidak perawan; 21,2\% remaja SMA mengaku pernah melakukan aborsi; Dari 2 juta wanita Indonesia yang pernah melakukan aborsi, 1 juta adalah pelajar remaja perempuan. Hasil survey BKKBN 2010 yang mengatakan bahwa 51\% pelajar Indonesia telah melakukan hubungan pranikah.

Lickona, T (dalam Megawangi, 2014) mengungkapkan bahwa ada sepuluh tanda-tanda jaman yang harus diwaspadai karena jika tanda-tanda ini sudah ada, maka itu berarti bahwa sebuah bangsa sedang menuju jurang kehancuran. Tanda-tanda yang dimaksud adalah :1. Meningkatnya kekerasan dikalangan remaja. 2. penggunaan bahasa dan kata-kata yang buruk. 3. Pengaruh peer group yang kuat dalam tindakan kekerasan,.4. meningkatnya perilaku merusak diri, seperti penggunaan narkoba, alcohol dan seks bebas, 5. Semakin kaburnya pedoman moral baik dan buruk. 6. Menurunnya etos kerja. 7. Semakin rendahnya rasa hormat kepada orang tua dan guru 8. Rendahnya rasa tanggung jawab individu dan warga negara, 9. Membudayakan ketidak jujuran, dan 10. Adanya rasa saling curiga dan kebencian di antara sesama..

Menurut Tafsir, A (dalam Amri Syafri, U. 2014:4), kesalahan terbesar dalam dunia pendidikan Indonesia selama ini adalah para konseptor pendidikan melupakan keimanan sebagai inti kurikulum nasional. Meskipun konsep-konsep pendidikan dalam UU Sisdiknas yang disusun pemerintah sudah menekankan pentingnya pembinaan akhlak dalam hal pembinaan moral dan budi pekerti, ternyata hal tersebut tidak diimplementasikan. Akibatnya pelaksanaan pendidikan di tiap lembaga tidak menjadikan pendidikan keimanan sebagai inti semua kegiatan pendidikan. Sehingga lulusan yang dihasilkan tidak memiliki keimanan yang kuat.

Berdasarkan permasalahan yang telah diuraikan diatas,, penanaman nilai-nilai IMTAQ dalam pendidikan terutama dalam proses pembelajaran IPA di sekolah mulai tingkat sekolah dasar merupakan sudah suatu keharusan bahkan suatu hal yang sudah argunsi. Sebagaimana yang dikemukakan oleh Marista (2011) bahwa pengembangan IMTAQ disekolah sangat penting sebagai upaya untuk mewujudkan tujuan pendidikan. Sesuai dengan UU NO. 20 Tahun 2003 pasal 3 yang berbunyi, "Pendidikan nasional berfungsi mengembangkan kemampuan dan membentuk watak serta peradaban bangsa yang bermartabat dalam rangka mencerdaskan kehidupan bangsa, bertujuan untuk berkembangnya potensi peserta didik agar menjadi manusia yang beriman dan bertaqwa kepada Tuhan Yang Maha Esa, berakhlak mulia, sehat, berilmu, cakap, mandiri, dan menjadi warga negara yang demokratis serta bertanggung jawab" 
Dalam upaya mencapai tujuan pendidikan sebagaimana yang diharapkan, salah satu factor yang sangat menentukan adalah faktor guru karena ia sangat tergantung seberapa besar pemahaman guru yang berkaitan kurikulum yang sedang berlaku dan mengimplementasikannya dalam proses belajar pembelajaran. Suyanto dan Jihad (2013) berpandangan bahwa guru yang profesional merupakan salah satu faktor yang sangat menetukan bahkan merupakan garda terdepan untuk menghasilkan kualitas lulusan sebagaimana yang diharapkan. Ibarat sebuah laboratorium, seorang guru seperti ilmuwan yang sedang bereksprimen terhadap nasib anak manusia dan juga suatu bangsa. Jika seorang guru tidak memiliki integritas keilmuan dan personalitas yang mumpuni, maka bangsa ini tidak akan memiliki masa depan yang baik. Hal yang sama juga dikemukakan oleh Robiah (2014) bahwa guru diharapkan memiliki kreatifitas yang tinggi dalam merancang dan menerapkan berbagai strategi dalam proses pembelajaran agar potensi siswa dapt berkembang secara optimal yang tidak hanya memiliki skill yang siap pakai dan mampu bersaing tapi juga memiliki benteng diri berupa keimanan yang kokoh dan tingkat ketakwaan yang tinggi kepada Allah SWT. Dengan demikian dalam proses pembelajaran sangat ditekankan agar guru dapat menerapkan strategi yang mengintegrasikan nilai-nilai Imtaq dengan Ilmu pengetahuan dan teknologi. Ayat-ayat al-Qur'an yang mengungkapakan fenomena alam cukup intensif dan prinsip-prinsipnya tidak ditemukan penolakan dari hasil temuan sains maupun sosial. Justru ayat-ayat al-Qur'an memuat banyak motivasi untuk mempelajari, merenungkan dan mengambil hikmah dari penciptaan alam semesta. Alam ini merupakan tanda-tanda kekuasaan Allah, dan kata-kata dalam al-Qur'an itu telah menjadi pendorong kepada umat Islam untuk mengkaji tentang fenomena alam. Banyak ayat al-Qur'an dan Hadits Rasul yang menyentuh secara umum dan khusus wilayah sains ini. Muatan ajaran Islam itu sendiri bisa dikaji melalui pendekatan ilmiah. Sebaliknya, sains diharapkan tidak berhenti pada penemuan terhadap gejala alam, sains dimaksudkan agar dapat membawa pada kontemplasi atau perenungan hingga sampai kepada Sang Pencipta (al-Khaliq) (Assegaf, dalam Hidayat M,2014). Apabila lembaga pendidikan ingin menciptakan manusia yang baik hendaknya memperhatikan bahkan mengutamakan pendidikan yang menyentuh ranah ruhaniyah atau keimanan. Dengan demikian, maka harapannya adalah dengan pendidikan akan mampu membuahkan manusia-manusia yang baik serta unggul dalam bidang agama dan sains (Ismali, M. 2014).

Pentingnya penanaman nilai-nilai imtaq pada anak didik didukung oleh pernyataan Sanjaya (2010) bahwa dalam masyarakat yang cepat berubah seperti dewasa ini, pendidikan nilai bagi anak merupakan hal yang sangat penting. Hal ini disebabkan pada era globalisasi dewasa ini, anak akan dihadapkan pada banyak pilihan tentang nilai yang dianggapnya baik. Pertukaran dan pengikisan nilainilai suatu masyarakat dewasa ini akan mungkin terjadi secara terbuka. Nilai-nilai yang dianggap baik oleh suatu kelompok masyarakat bukan tak mungkin akan menjadi luntur digantikan oleh nilai-nilai baru yang belum tentu cocok dengan budaya masyarakat. Sabda Rasulullah SAW ."Didiklah anakanakmu, karena mereka itu diciptakan buat menghadapi zaman yang sama sekali lain dari zamanmu kini."

Penanaman nilai-nilai imtaq pada anak didik dalam proses pembelajaran merupakan wacana yang sudah cukup lama digulirkan oleh pakar pendidikan dan juga merupakan salah satu tujuan dari pendidikan nasional. Namun demikian faktanya pelaksanaan proses pembelajaran disekolah/perguruan tinggi pada umumnya tetap berjalan secara terpisah (dikotomi), walaupun ada yang melaksanakannya namun persentasinya sangatlah kecil. Banyak factor penyebab wacana tersebut tidak dapat di implementasikan dengan baik, kemungkinan diantaranya ketidak pahaman guru untuk pengintegrasian tersebut, adanya pandangan dari kalangan pendidik bahwa persoalan imtaq merupakan tanggung jawab dari guru agama, disamping itu adanya kecendrungan dalam proses pembelajaran selama ini yang lebih mementingkan aspek kognitif saja, selalu adanya keluhan masalah tidak cukupnya waktu karena materi ajar yang terlalu padat dan lain sebagainya.

Namun demikian pada dasarnya sebagian guru setuju bila adanya pengitegrasian IMTAQ dalam proses pembelajaran namun mereka berpandangan sulit untuk dilaksanakan karena tidak adanya bahan ajar yang dapat dijadikan sebagai acuan dan disamping itu menurut para guru perlu adanya pembekalan melalui pelatihan agar tidak terjadi kesalahan dalam implementasinya.

Berdasarkan permasalahan yang telah dikemukakan diatas, maka pengintegrasian nilai-nilai Al-qur'an khususnya nilai-nilai imtaq dan Sains dalam proses pembelajaran merupakan suatu hal sudah urgensi dilakukan oleh guru. Uuntuk kepentingan tersebut perlu adanya pembekalan dan pelatihan pemantapan penguasaan bahan ajar IPA yang berbasis Al-qur'an atau IMTAQ pada guru-guru 
Buletin Pembangunan Berkelanjutan

Vol. 5 No. 3, Desember 2021 hal. 54-60 SD dengan harapan nantinya dapat di implementasikan kepada peserta didik dalam proses belajar pembelajaran.

\section{METODE PELAKSANAAN}

Metode pelaksanaan yang digunakan pada pengabdian masyarakat ini menggunakan metode pelatihan, dengan lokasi pelatihan di Sekolah Dasar Negeri 003 Sekar Mawar Kecamatan Pasir Penyu Kabupaten Indragiri hulu dan peserta pelatihan dari gru-guru SD berjumlah 25 orang pelatihan dilakukan selama 2 hari.

\section{HASIL DAN PEMBAHASAN}

Kegiatan pengabdian Masyarakat berupa pelatihan pemantapan penguasaan bahan ajar IPA terintegrasi nilai-nilai Al-qur'an untuk guru-guru SD di Sekolah Dasar Negeri 003 Sekar Mawar kecamatan Pasir Penyu Kabupaten Indragiri Hulu selama 2 hari telah dilaksanakan dengan baik. Pelatihan telah diikuti oleh 25 orang guru SD. Kegiatan berjalan dengan lancar dan guru-guru telah memiliki bekal penguasaan materi dari bahan ajar yang telah diberikan walaupun belum optimal, hanya saja diharapkan guru-guru yang telah mengikuti pelatihan dapat selalu mengimplemetasikan kepada peserta didik agar menjadi pembiasaan dan murid mendapatkan ilmu IPA yang utuh sebagaimana karakteristik IPA itu sendiri yang mengandung ayat-ayat qauniyah dan Qauliyah.

Berikut ini contoh materi yang telah diberikan kepada peserta pelatihan.

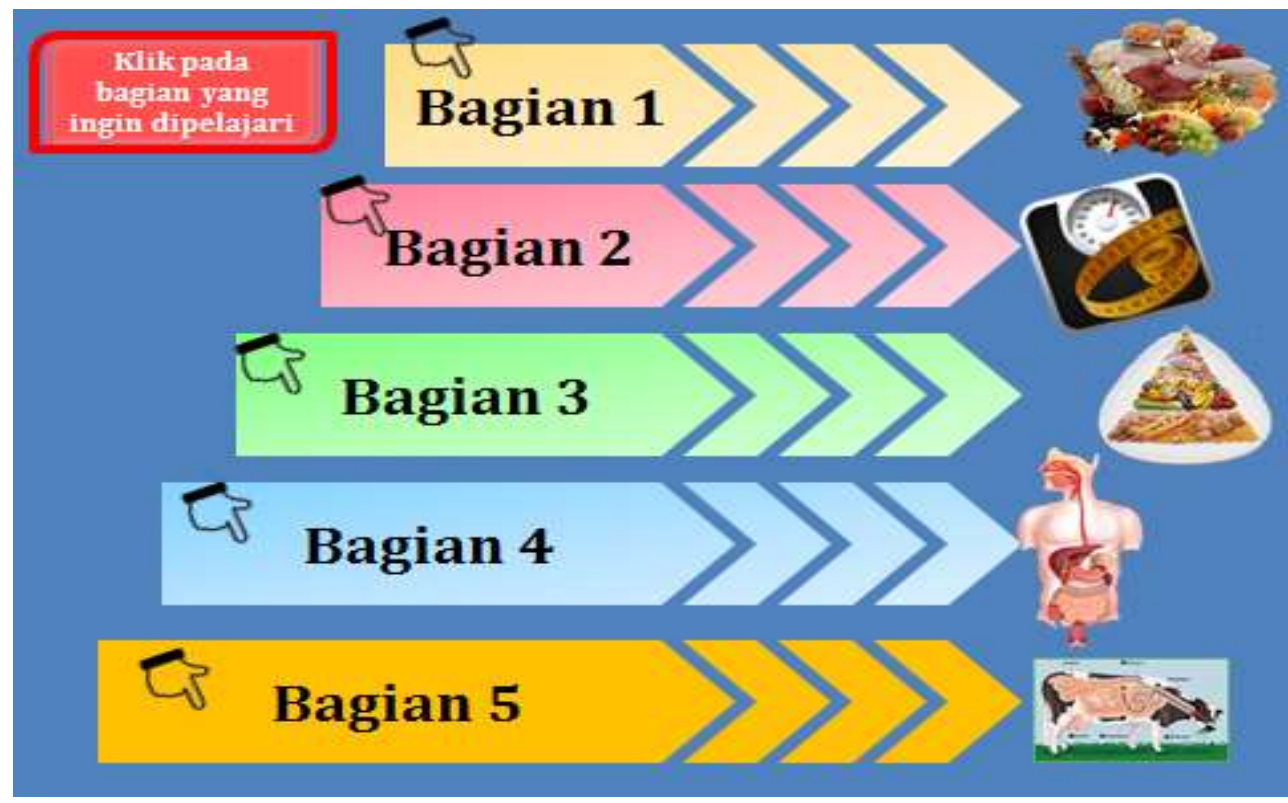

Gambar 1. Contoh Materi Yang Diberikan 


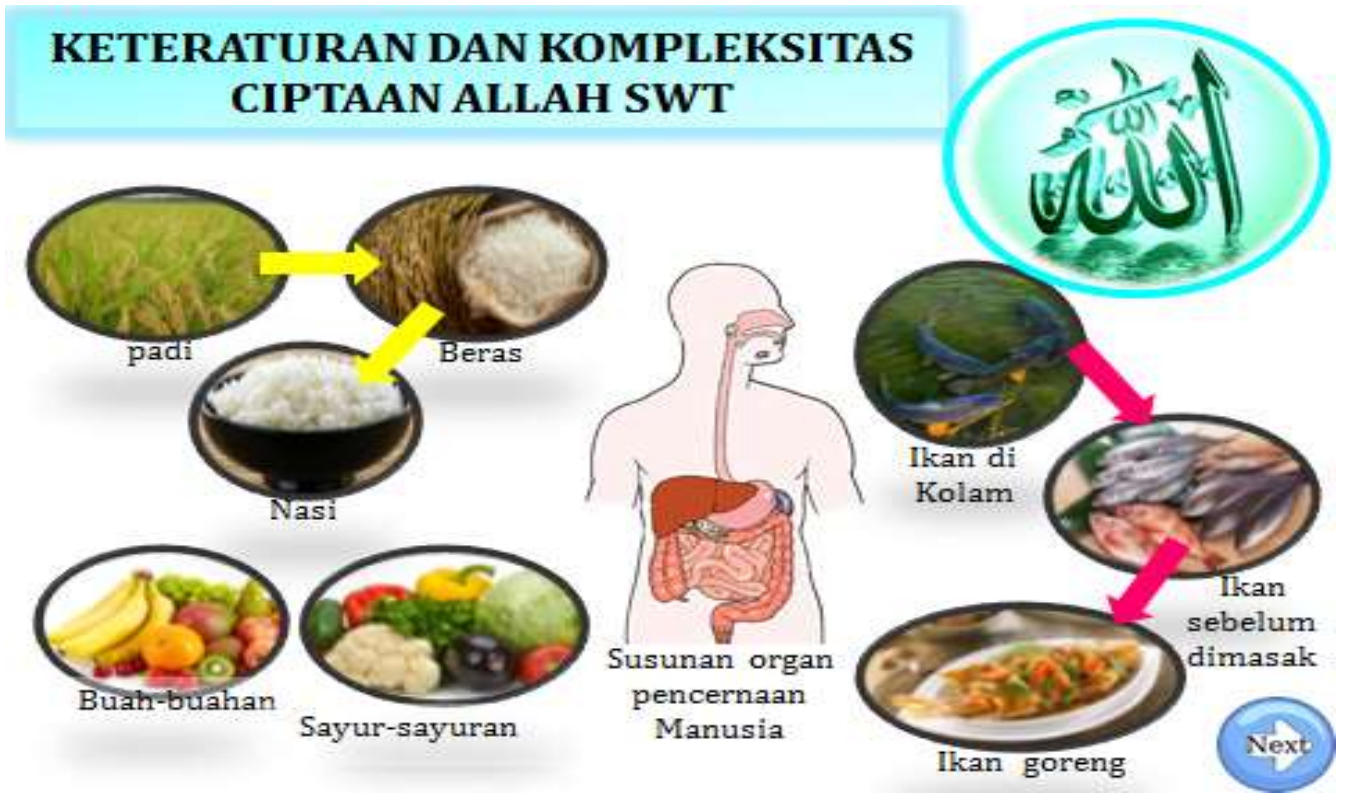

Gambar 2. Berbagai Jenis Makanan Ciptaan Allah SWT

Allah berfirman dalam surat Fushshilat ayat 53 yang berbunyi:

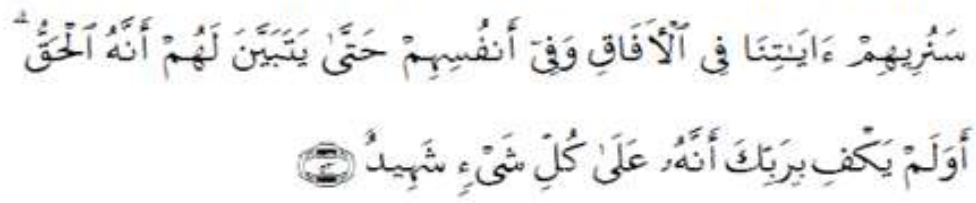

"Kami akan memperlihatkan kepada mereka tandatanda (kekuasaan) Kami di segenap ufuk dan pada diri mereka sendiri, sehingga jelaslah bagi mereka bahwa Alquran itu adalah benar. Dan apakah Tuhanmu tidak cukup (bagi kamu) bahwa sesungguhnya Dia menyaksikan segala sesuatu?" (QS. Fushshilat: 53).
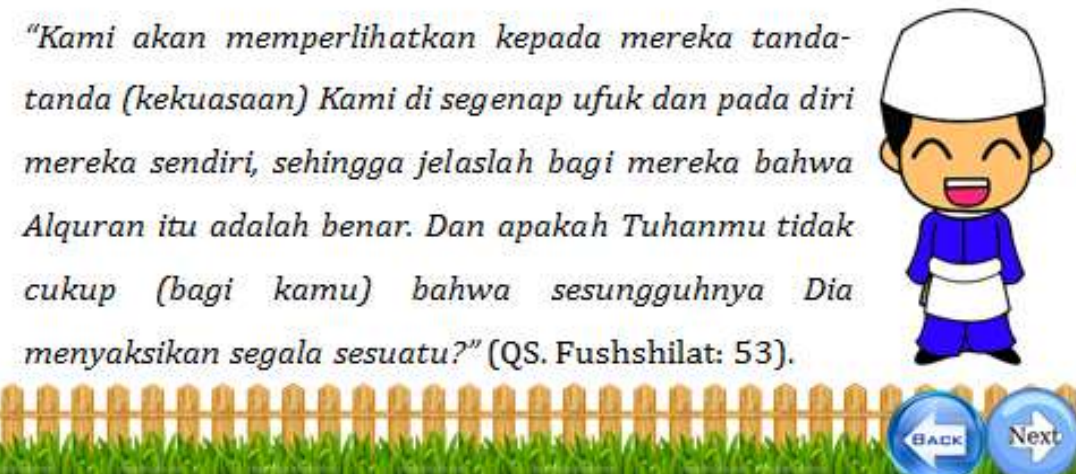

Gambar 3. Ayat Al-Qur'an Terkait dengan Materi 
Buletin Pembangunan Berkelanjutan

Vol. 5 No. 3, Desember 2021 hal. 54-60

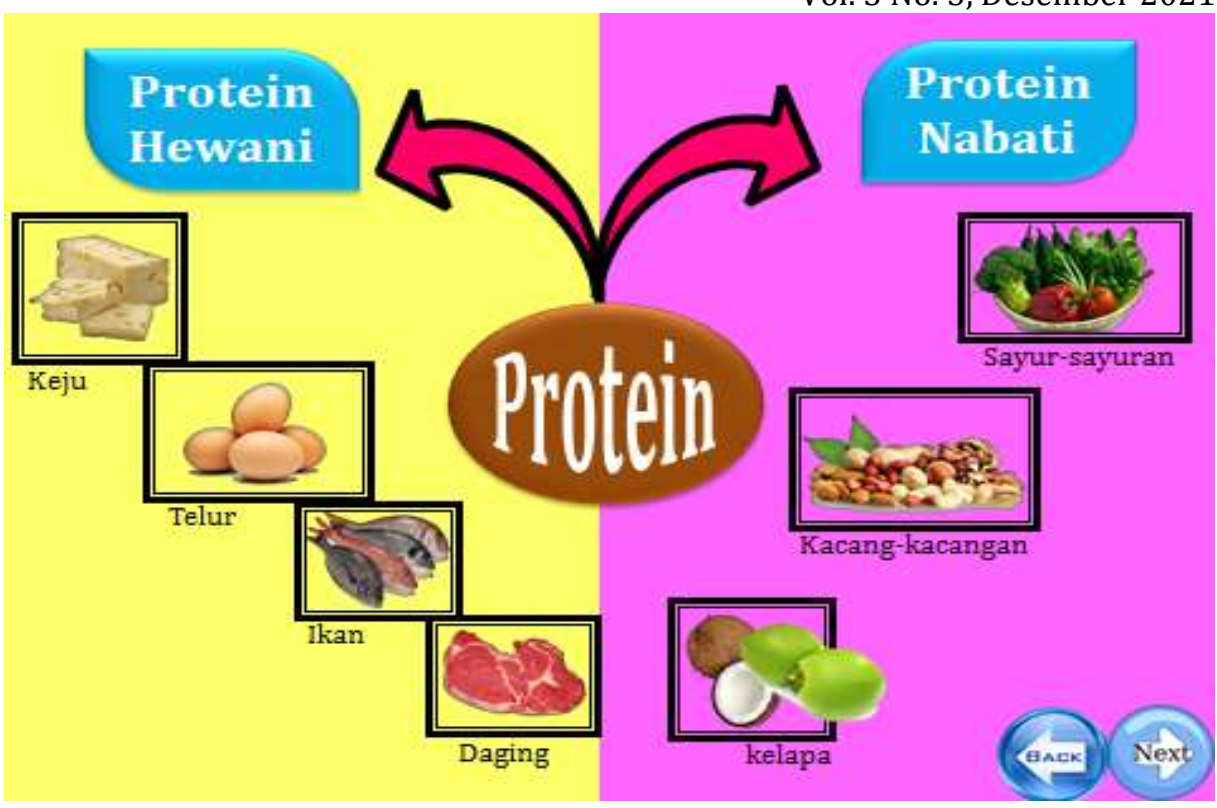

Gambar 4. Berbagai Jenis Makanan Mengandung Protein

Dalam Alquran surat Al-Maidah ayat 90 Allah menyatakan bahwa meminum khamar merupakan perbuatan dosa

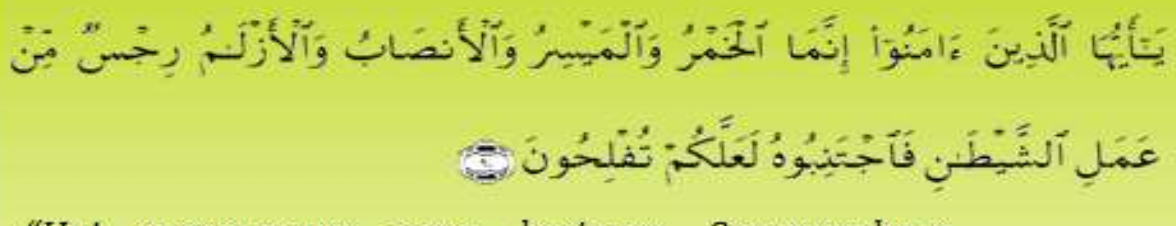

"Hai orang-orang yang beriman, Sesungguhnya (meminum) khamar, berjudi, (berkorban untuk) berhala, mengundi nasib dengan panah [434], adalah Termasuk perbuatan syaitan. Maka jauhilah perbuatan-perbuatan itu agar kamu mendapat keberuntungan". (QS. Al-Maidah: 90)

Gambar 5. Ayat Al-Qur'an Terkait Dengan Materi

\section{KESIMPULAN}

Berdasarkan kegiatan pengabdian masyarakt yang telah dilakukan maka dapat disimpulkan bahwa guru-guru SD kabupaten Indragiri hulu yang telah mengikuti pelatihan telah memiliki bekal penguasaan Bahan Ajar IPA yang terintegrasi Imtaq dengan baik walaupun belum optimal dan diharapkan guru-guru dapat mengimplemetaikannya kepada peserta didiknya. Selanjutnya kegiatan ini diharapkan dapat dilakukan pada guru-guru SD lainnya dan juga pada sekolah SMP dan SMA atau sekolah sederajat dengan harapan didukung oleh semua pihak terutama Lembaga Penelitian dan pengabdian Masyarakt Universitas Islam Riau.

\section{UCAPAN TERIMA KASIH}

Terimakasih kepada Lembaga Penelitian dan Pengabdian Masyarakat (LPPM) yang telah memberikan dukungan dana sehingga kegiatan ini dapat dilaksanakan dengan baik 


\section{DAFTAR PUSTAKA}

Azra, A. (2012). Pendidikan Islam, Tradisi dan Modernisasi di Tengah Tantangan Millenium III, Jakarta. Kencana Prenada Media Group.

Darnanengsih, 2020. Internalisasi Nilai-Nilai Karakter Dalam ProsesPembelajaran Untuk Membentuk KarakterPeserta Didik (Studi Kasus Di SMA Averos Kota Sorong Papua Barat), Jurnal AlRiwayah: Jurnal Kependidikan Volume, 12 (1).

Gunawan, H. (2014). Pendidika Islam Kajian Tioritis dan Pemikiran Tokoh, Bandung: PT. Remaja Rosdakarya.

Hidayat, M. 2014. Pendekatan Integratif-Interkonektif: Tinjauan Paradigmatik dan Implementatif Dalam Pembelajaran Pendidikan Agama Islam. Jurnal A'DIB, Vol. XIX (2).

Ismail, M. (2014). Konsep Berfikir Dalam Al-Qur'an dan Implikasinya Terhadap Pendidikan Akhlak. Jurnal TA'DIB, Vol. $X I X,(2)$

Jayadi, I (2018). Sifat-Sifat Pendidik Perspektif Al-qur'an. Jurnal Al-Riwayah: Jurnal Kependidikan Volume, 10 (2).

Marzuki, (2015). Pendidikan Karakter Islami. Jakarta. Amzah.

Megawangi, R. (2014). Pendidikan Karakter, Solusi Yang Tepat Untuk Membangun Bangsa. Bogor: Indonesia Heritage Foundation.

Mulyasa, E. (2013). Pengembangan dan Implementasi Kurikulum 2013, PT.Remaja Rosdakarya, Bandung.

Nafila, NH $d k k$. (2016). Penerapan Pembelajaran Biologi Berbasis Iaman dan Taqwa Pada Konsep Sistem Reproduksi Manusia Untuk Meningkatkan Keterampilan Berfikir Kritis Siswa Kelas XI SMA Negeri I Ciwaringin, Scientiae Educatia: Jurnal Sains dan Pendidikan Sains Vol. 5 (2).

Nasution, AS, Lubis, SA, dan Mukti, A, (2019). Peran Pendidikan Agama Islam Dalam Menghempang Perilaku Lesbian, Gay, Biseksual, Transgender di Kota Medan. Jurnal At-Tazakki: Vol 1 (3).

Robiah,S. (2014). Proceeding The 8Th International Conferenci On Indonesia-Malaysia Relation, Pekanbaru.

Sanjaya, W. (2010). Strategi Pembelajaran Berorentasi Standar Proses Pendidikan, Prenada Media Group, Jakarta.

Siregar B, Zein A dan Zulheddi, 2018. Pendidikan Akidah Dalam QS.Al-Hasyr Ayat 22-24 Menurut Perspektif Jamal Al-Din Al-Qasimi, Jurnal At-Tazakki: Vol.2(2).

Suyanto dan Jihad, (2013). Menjadi Guru Profesional, Strategi Meningkatkan Kualifikasi dan Kualitas Guru di Era Global, Esensi Erlangga group. Jakarta.

Syafri, U (2014). Pendidikan Karakter Berbasis Alqur'an, Jakarta: Rajawali Press. 